\title{
Pés no além, olhar na terra: um estudo em quatro peças vicentinas
}

\author{
Stélio Torquato Lima ${ }^{1}$ \\ http://lattes.cnpq.br/1661081147524477
}

Enviado em: 19/08/2018

Aceito em: 23/11/2018

\begin{abstract}
RESUMO: O dramaturgo português Gil Vicente erigiu sua obra teatral entre dois mundos, o medieval e o renascentista. Essa condição fomentou em muitas de suas peças uma aparente contradição: embora se passando em um cenário post mortem, os enredos se ocupam claramente com questões terrenas. Nessa perspectiva, este trabalho se volta para análise de algumas das formas como essa aparente contradição se evidencia em quatro autos vicentinos, cujas datas de criação estão bastante aproximadas (entre 1517 e 1519): o Auto da Alma e as peças que compõem a trilogia das barcas (o Auto da Barca do Inferno, o Auto da Barca do Purgatório e o Auto da Barca da Glória).
\end{abstract}

Palavras-Chave: Teatro Vicentino; Medievo; Renascimento

ABSTRACT: The Portuguese playwright Gil Vicente developed his works between two worlds, the Middle Age and the Renaissance. This condition fomented in many of his plays an apparent contradiction: although located in a post-mortem scenario, the plots are clearly concerned with earthly matters. In this perspective, this work turns to analyze some of the ways in which this apparent contradiction is showed in four Vincentian plays, whose dates of creation are very approximate (between 1517 and 1519): the Auto da Alma and the autos that make up the trilogy of the barges (the Auto da Barca do Inferno, the Auto da Barca do Purgatório and the Auto da Barca da Glória).

Keywords: Vicentino Theater; Middle Age; Renaissance

\section{Introdução}

Gil Vicente (c.1465 - c.1537) viveu durante um período de grandes transformações na economia, na política e na cultura de Portugal. Ainda sob o reinado da dinastia de Avis (1385-1580), que promoveu uma grande renovação da cultura nacional, o país tinha se expandido com a tomada de Ceuta (1415), a descoberta de Cabo Verde (1460), a chegada de Vasco da Gama às Índias (1498), a descoberta do Brasil (1500), etc.

As Grandes Navegações e o desenvolvimento do comércio reforçaram a crença no poder da capacidade intelectual e do empreendedorismo humano, trazendo o homem para o centro das discussões, inclusive no plano literário. Nascia assim um novo modelo de representação, no qual o Teocentrismo ia cedendo lugar ao Antropocentrismo. Por outro lado, como reação à Reforma de Lutero, o Catolicismo procurou fortalecer sua doutrina com o fim de impedir o avanço do Protestantismo, o que fez se multiplicar em Portugal as obras que gravitavam em torno de assuntos de interesse da Igreja, como a discussão do valor das virtudes cristãs, logicamente, sempre na perspectiva de Roma.

A Igreja Católica, portanto, exercia grande poder durante o período em que Gil Vicente

\footnotetext{
${ }^{1}$ Docente do Departamento de Literatura da Universidade Federal do Ceará, coordenador do grupo de estudos literatura Popular e poeta-cordelista.

E-mail: profstelio@yahoo.com.br
} 
compôs suas obras. Nesse pormenor, convém lembrar que nem na prática e nem pela lei havia em Portugal uma separação entre Igreja e Estado à época, sendo muito coincidentes os interesses da Nobreza e do Clero. Ademais, constituindo-se de um teatro essencialmente didático e marcado pela exemplaridade, a obra vicentina encontrava na Bíblia e na pregação católica uma referência fundamental para o desenvolvimento dos enredos.

Em decorrência da herança vinda do período medieval, no qual a discussão da fé se impunha, observa-se que a religiosidade constitui um dos temas centrais da obra teatral de Gil Vicente. Atesta isso o fato de muitas peças do autor se constituírem de autos, obras que tinham a finalidade de divertir, moralizar e/ou difundir a fé cristã e nas quais é frequente a presença de figuras bíblicas, de santos ou de figuras alegóricas representativas de valores (ou defeitos) da Cristandade. São exemplos, entre tantos outros títulos, o Auto da Visitação (1502), o Auto da Barca do Inferno (1517) e o Auto da Alma (1518)2.

Como efeito dessa visita constante aos textos religiosos, o teatro vicentino acha-se povoado por personagens das narrativas cristãs, muitas delas construídas a partir da personificação de virtudes ou defeitos de caráter - santos, anjos, demônios, a alma, a fé etc. $\mathrm{O}$ palco das narrativas, da mesma forma, não raro se situa num território sobrenatural característico do imaginário medieval. Exemplo é o lugar em que se acham as barcas que transportam as almas para o céu ou para a morada dos perdidos em O Auto da Barca do Inferno.

Nesse processo logicamente, a religião veio a ocupar lugar central na obra vicentina, para o que contribuiu D. Leonor, viúva do rei D. João II e protetora de Gil Vicente:

A influência do espírito excessivamente religioso da viúva de D. João II encaminhou naturalmente o seu gênio renovador para a figuração mística dos temas sacros. Foi assim que o poeta começou por utilizar, entre todos os elementos populares, as figuras pastoris, mais simples e mais ingênuas com que iniciou o teatro hierático (PRATT, 1931, p. 27).

Entretanto, mesmo sem desconsiderar o papel de D. Leonor, a temática da fé se colocava como uma herança medieval, e mais propriamente do teatro medieval, haja vista que

Tal como acontecera com o teatro grego, o teatro medieval, antepassado do moderno teatro ocidental, nasceu do culto. A missa católica era já um simbólico drama: drama na sua forma, pelos cantos alternados com a recitação, pelo diálogo do oficiante e dos coadjuvantes e fiéis, drama também no seu fundo pela comemoração simbólica do sacrifício. (JANEIRO, s.d., p. 32)

Todavia, ainda que situando o cenário de muitas peças num território sobrenatural próprio do post mortem, Gil Vicente nunca se afastou do chão duro de sua realidade. Assim, ao mesmo tempo em que seu teatro, pincipalmente as "obras de devoção", celebravam a fé, estas também se prestavam à crítica da Igreja e da nobreza. Esta crítica, diga-se de passagem, não deixava de ter apoio da realeza, que via nas peças de Gil Vicente um meio de combater as falhas de conduta da nobreza e do clero:

É oportuno salientar que Gil Vicente fora favorecido pelo rei com o privilégio de exercer livremente a crítica sobre os desregramentos do clero e a dissolução dos costumes no seio da nobreza. As representações dos autos vicentinos realizavam-se perante a corte e religiosos, algumas vezes na capela real, outras nas igrejas e mosteiros, porque os monarcas europeus, em sua maioria, apoiavam a liberdade de expressão

\footnotetext{
2 Apesar de a didascália inicial da peça supostamente trazer a data de 1508, autores como Braancamp Freire, I. S. Révah e Antonio José Saraiva não têm dúvidas de que o ano correto da primeira encenação é 1518, visto D. Manuel não se encontrar na cidade em 1508. O que teria acontecido, na verdade, foi um equívoco, tendo sido considerado o 1 após o 5 como sendo o símbolo \&.
} 
da comédia, considerada manifestação autêntica do sentimento popular e instrumento de opinião. (MOREIRA, 2005-b, p. 21)

Assim, as chamadas "obras de devoção" de Gil Vicente, que compõem uma das cinco partes da Compilação organizada por Luís Vicente, filho do dramaturgo, trazem uma interessante costura entre o culto da fé e das virtudes cristãs por um lado, e a crítica da classe dominante por outro, com destaque para os sacerdotes. Como desdobramento disso, observa-se o trânsito entre o Além e a terra, entre o espírito e o corpo, em que os cenários e personagens do post mortem não raro figuram como máscaras dos componentes do entorno social em que vivia o autor.

Partindo dessa premissa, este trabalho se volta para análise de algumas das formas como a aparente contradição entre natural e sobrenatural, sagrado e profano, vida e morte, etc. se evidencia em quatro autos vicentinos, cujas datas de criação estão bastante aproximadas (entre 1517 e 1519): o Auto da Alma e as peças que compõem a trilogia das barcas (o Auto da Barca doInferno, o Auto da Barca doPurgatório e o Auto da Barca daGlória). Antecedendo a análise de trechos dessas quatro peças, apresenta-se uma abordagem do contexto em que Gil Vicente as escreveu, com ênfase sobre a singular relação que o poeta manteve entre o legado medieval e a nova mentalidade que o Renascimento trazia.

\section{Um Autor entre Dois Mundos}

A alternância entre os variados períodos literários pode ser representada grosso modo a um movimento pendular que ora tende para o realismo, para a objetividade e/ou para o terreno (Classicismo, Arcadismo, Realismo/Naturalismo e Parnasianismo), ora se volta para o idealismo, para o subjetivismo e/ou para o sobrenatural (Barroco, Romantismo e Simbolismo). A ação desse pêndulo se observa, por exemplo, no trânsito entre as estéticas caracterizadoras do Medievalismo e do Renascimento: ao teocentrismo do primeiro, seguese o antropocentrismo do segundo, com as questões ligadas à espiritualidade cedendo espaço a discussões mais associadas à materialidade e à capacidade empreendedora humana.

Gil Vicente produziu sua obra teatral exatamente entre esses dois mundos, o medieval e o renascentista: situando-se cronologicamente entre o fim do primeiro e o alvorecer do segundo, o autor via de diante de si duas maneiras de fazer e pensar o teatro, como assinala Reis Brasil: "Gil Vicente encontrou duas grandes tendências teatrais: a que vinha da pura medievalidade; [e] a que lhe era apresentada pelos renascentistas com a possível reintegração dos modelos greco-latinos, embora adaptados aos novos temas" (BRASIL, 1965, p. 16). Entretanto, como assinala o pesquisador, Gil Vicente fez sua opção pela tradição, mais afinada tanto a sua cosmovisão como aos anseios do seu público:

Gil Vicente conheceu perfeitamente essas duas correntes; Gil Vicente teve uma sólida cultura renascentista, como ele mostra, embora esporadicamente.

Contudo, o seu gênio viu que não era esse o caminho que devia seguir. Gil Vicente teve um conhecimento integral das doutrinas do Cristianismo, que defende com uma clarividência [...] digna do todos aqueles que ainda [...] estão convencidos de que nada mais dignifica o homem do que a prática do bem integral para com todos os seus semelhantes. Contudo, essa prática da criação do homem social não podia fazer-se com ideologias ou teorias; era preciso mostrar as realidades da vida, as realidades da religião, as dificuldades do homem que sofre, quando é explorado pela prepotência dos que abusam da sua situação. (BRASIL, 1965, p. 17)

Portanto, embora Gil Vicente seja "considerado um autor de transição entre a Idade 
Média e o Renascimento, [mostrou-se] mais voltado para a tradição do que para a modernidade" (BERARDINELLI, 1971, p. 9). Nessa perspectiva, pode-se apontar como uma primeira evidência da sua preferência pelo teatro do medievo o fato de ele não ter obedecido em suas peças à regra das unidades de tempo, lugar e ação exigidas pelo Classicismo, referência estética e ideológica dos renascentistas.

Outro fator que se soma ao já citado é a limitação da sua galeria de personagens ao mundo feudal, excluindo, assim, aqueles que representavam o novo mundo social que surgia com o Renascimento, como explica António José Saraiva:

\begin{abstract}
Os tipos vicentinos abrangem o conjunto da sociedade portuguesa da sua época. Na base está o camponês "pelado" por fidalgos e clérigos, a cuja voz Gil Vicente dá acentos comoventes. No cume estão os clérigos de vida folgada e os fidalgos presunçosos e vãos, que vivem, uns e outros, de confiscar o trabalho alheio, ajudados pelos homens de leis e pelos altos funcionários, que fabricam "alvarás" em benefício dos seus afilhados. À volta dos fidalgos enxameiam os escudeiros, ociosos, gabolas e "rascões", que dão caça aos dotes das burguesas remediadas. Têm especial vigor os tipos do que poderíamos chamar a "classe média" desta hierarquia: a "moça de vila" e o escudeiro. É de notar a quase ausência de artífices e negociantes, o que talvez se explique pelo próprio ponto de vista burguês em que se coloca Gil Vicente, e o leva a focar principalmente as personagens características do mundo feudal. (SARAIVA, s.d. p. 1920)
\end{abstract}

Também Óscar de Pratt, após acentuar que Gil Vicente traça como nenhum outro cronista da época um retrato "da vida íntima da sociedade portuguesa do século XV, desde as tabernas sombrias até os salões pomposos da corte” (PRATT, 1931, p. 11), realça a quase inexistência de figuras ligadas ao mundo renascentista que nascia:

Mas a atividade febril em que se desenvolviam o comércio e navegação da Etiópia e da Índia, e que fazia vibrar intensamente os nervos da nação, não conseguiu empolgar a imaginação do poeta. A esfera da sua visualidade crítica gira em volta desse centro de perturbação nacional, colhendo apenas na passagem certos agentes ou produtos de efervescência. (PRAT'T, 1931, p. 265)

Para além disso, a medievalidade se evidencia na obra vicentina pelo aproveitamento das formas teatrais que vinham da tradição e pela fixação da mentalidade do período, em que prevaleciam a ideologia cavalheiresca e a religião cristã (Cf. JANEIRO, s.d., p. 53-54). Já no tocante às formas, Cleonice Berardinelli lembra que

Em todo o seu teatro, Gil Vicente mantém-se fiel às formas medievais, utilizando metros e estrofes que se encontram no Cancioneiro Geral: os versos de arte-menor (o redondilho maior, de sete sílabas e o redondilho menor, de cinco) e os versos de arte-maior (basicamente com onze sílabas, com cesura na quinta), agrupados em estrofes de extensão variável (oito, nove, dez, catorze versos...). (BERARDINELLI, 1971, p. 13. Grifos da autora)

Analisando a questão de outro ângulo, Armando Martins Janeiro lembra que o teatro vicentino dialoga com gêneros do teatro medieval, que incluía modalidades como os mistérios e as moralidades. Nestes, a propósito, já estavam presentes elementos que marcariam o teatro de Gil Vicente: "Nos mistérios aparecem já personificações de caracteres bíblicos e qualidades morais. Foi daqui que provavelmente derivou um novo tipo de peça medieval, a moralidade. $\mathrm{Na}$ moralidade, as figuras representam personificações abstratas, geralmente das virtudes e dos vícios" (JANEIRO, s.d., p. 36-37. Grifos do autor).

Nesse contexto, Gil Vicente teve como ponto de partida alguns dos gêneros do teatro religioso medieval, os quais, associados à sátira, deu-lhe o material necessário para unir a celebração dos ideários cristãos, das virtudes da cristandade, com a crítica social: 
Pois bem, toda a teoria cristã de mistérios e moralidades, as infinitas repetições dos temas da Natividade, da Ressurreição e da Paixão, encontram-se consubstanciadas nos autos de Gil Vicente. E também o característico humor na Idade Média, o seu prazer dos jogos e da folia, a sua ingenuidade pitoresca e o seu descaro, o seu riso espontâneo e grosso, a sua turbulência, se encontram resumidos nas farsas e comédias vicentinas. (JANEIRO, s.d., p. 53-54)

Esse movimento que vai do céu à terra, da fé à denúncia social, dá testemunho da religiosidade que Gil Vicente abraçou, a qual não foi refratária à crítica do clero que suscitou a Reforma de Lutero, mostrando o tipo de humanismo que o dramaturgo português adotou:

Sua [de Gil Vicente] religiosidade [...], sua ternura filial pela Virgem Maria, seu carinho pelo menino Jesus, tudo nos assegura que ele mantém pura e inabalável a sua fé - como homem da Idade Média -, mas se permite censurar os desmandos dos que a representam na Terra - como homem do Renascimento. E porque é preciso castigar para corrigir, a nota da sátira, aguda, estridente, por vezes abafa a suave melodia das loas ao Senhor.

Mas a fé do Mestre Gil é fé de católico ortodoxo que crê em Deus e obedece, submisso, à Madre Igreja Santa (cf. Auto da Fê). Essa submissão ao espírito da Igreja não lhe tira, no entanto, a lucidez para julgar Roma, a igreja temporal, com as suas "torpidades". (BERARDINELLI, 1971, p. 10. Grifos nossos)

É importante lembrar que a incorporação à discussão da fé dessa constante crítica social, com destaque para a denúncia dos desregramentos da Igreja, constitui uma modernização dos conteúdos herdados do teatro medieval, configurando-se em uma das facetas renascentistas da obra vicentina, tendo em vista que,

não obstante a sua vinculação à herança medieval, alguns dos seus autos e farsas apresentam traços clássicos e renascentistas, principalmente pela intencionalidade moralizadora de sátira irreverente, pela crítica audaciosa, que põe em xeque a questão das indulgências, pela teimosa ousadia de satirizar a escolástica, a conduta do clero e, finalmente, pela introdução de elementos da mitologia em algumas peças. (MOREIRA, 2005-a, p. 18)

Como se pode perceber, a condição intervalar de Gil Vicente leva a uma relação singular, e por vezes problemática, com a tradição e com a modernidade, em que o autor procura aproveitar ao máximo elementos das duas estéticas para melhor dar expressão ao seu pensamento. Nesse pormenor, Reis Brasil (BRASIL, 1965, p. 16-17) observa que o aproveitamento de elementos tanto do teatro medieval quanto do teatro renascentista foi algo complicado para Gil Vicente, que nem sempre conseguiu encontrar em ambos os moldes necessários para dar expressão aos seus pensamentos.

Já António José Saraiva, rediscutindo em outros moldes a condição do medievo como base de construção da obra vicentina, não hesita em ver o teatro do autor luso como demarcador do fim do teatro medieval. Para ele, a obra de Gil Vicente promove a desagregação da unidade simbólica do teatro religioso. Como desdobramento da nova realidade que o teatro vicentino institui, explica Saraiva, a oposição Luz-Sombra (ou Bem-Mal), própria do teatro religioso, ganha em complexidade, se torna mais abrangente: em sintonia com a mentalidade antropocêntrica de fundo renascentista, novas oposições emergem à superfície das obras, como Espírito-Matéria e Infinito-Finito, permitindo dialeticamente a discussão Além-Terreno:

Mas, emergindo deste meio indiferenciado e túmido de virtualidades, este simbolismo desenvolve-se numa estrutura mais complexa. A oposição Luz-Treva adquire novo conteúdo. A análise da antinomia Bem-Mal pode revelá-la redutível a esta outra antinomia Espírito-Matéria, ou ainda Infinito-Finito. (...). 
A luminosidade permanece como representação simbólica do mundo a que Gil Vicente chama "glória resplandecente"; enquanto no mundo sombrio, a análise desfibra traços e planos múltiplos. O contraste consiste agora nesta mesma diferença entre a expressão simbólica e a expressão realista: o mundo do infinito é definido por oposição ao mundo real (isto é, realizado). Supera-se deste modo o primitivo jogo da Luz e Sombra. (SARAIVA, 1981, p. 157-158)

A partir dessa fixação por Gil Vicente da discussão frequente entre a oposição entre o mundo do infinito e o mundo real, à qual não falta uma nota de neoplatonismo, as peças do autor, notadamente as designadas como "obras de devoção", ganharam contornos que assinalam o hibridismo tanto espacial (misto do além e do terreno) quanto temporal (o tempo do post mortem e a temporalidade humana), com desdobramentos sobre a composição das personagens dessas obras. Nesse contexto, passamos a ver como essa combinação dos dois mundos é figurada em quatro peças do autor, o Auto da Alma e os três autos que compõem a trilogia das barcas: o Auto da Barca do Inferno, o Auto da Barca do Purgatório e o Auto da Barca da Glória.

\section{Uma Obra entre Dois Palcos Diegéticos}

A condição intervalar de Gil Vicente, posto ter produzido na fronteira entre o mundo medieval e o renascentista, projeta-se em sua obra dramatúrgica de diferentes formas, afetando a tríade em que se apoiam as estruturas narrativas: tempo-espaço-personagem. Em relação ao tempo, por exemplo, observa-se que, com exceção do Auto da Alma, que se desenvolve ainda durante a existência terrena, os autos que compõem a "trilogia das barcas", embora se operando numa temporalidade post mortem, desenvolvem-se em um momento muito próximo às mortes das personagens. Tanto é assim que muitas delas ainda se mostram confusas, sem a consciência plena de sua nova condição. Exemplo é a regateira Marta Gil, personagem do Auto da Barca do Purgatório:

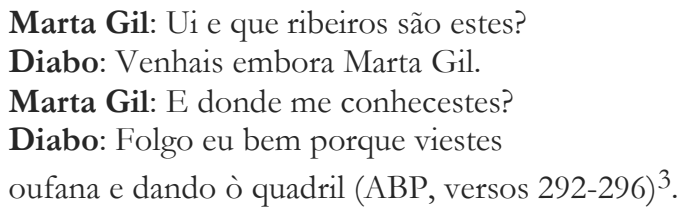

Semelhantemente ao tempo, os espaços das quatro peças aqui analisadas se situam na fronteira entre o post mortem e o plano terreno: a "trilogia das barcas" se passa em uma espécie de antessala do além, haja vista ter como cenário uma espécie de porto em que se definem os destinos das almas - Céu, Inferno ou Purgatório. Já o Auto da Alma, embora situado ainda num plano terreno, desenvolve-se em uma dimensão espiritual, fruto da condição alegórica das personagens (o ideário da Igreja figurado na figura dos teólogos católicos, etc.), dos lugares (a estalagem, por exemplo) e dos objetos (o alimento da alma, entre outros).

Como efeito de um tempo e de um espaço diegéticos ainda vizinhos ao da existência terrena, não se observa nas peças em análise a extinção das leis naturais que regem a vida

\footnotetext{
3 Todos os trechos das peças de Gil Vicente citados neste trabalho foram extraídos do site do Centro de Estudos de Teatro, seção Teatro de Autores Portugueses do Séc. XVI, da Universidade de Lisboa, disponível em http://cet-equinhentos.com/info. Por essa razão, optou-se em indicar apenas o número (posição) dos versos citados e a abreviatura dos títulos das peças analisadas: AA (Auto da Alma), ABI (Auto da Barca do Inferno), ABP (Auto da Barca do Purgatório) e ABG (Auto da Barca da Glória).
} 
humana: no post mortem vicentino, as personagens não são expostas a uma nova ordem, em que não mais vigoram fenômenos como a gravidade, o envelhecimento, a fome, etc. Veja-se, a esse respeito, a zombaria da fala do parvo Joane ante a impossibilidade de subir à barca do Diabo antes que este mandasse descer a tábua de acesso:

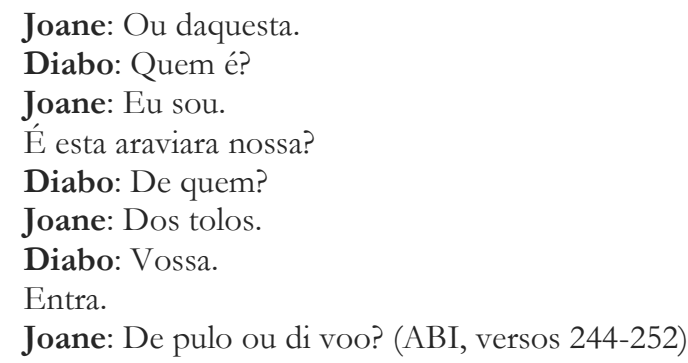

Significativa também é a alusão tanto à necessidade do alimento quanto ao envelhecimento da alma no Auto da Alma, como se esta estivesse condicionada às mesmas leis a que os corpos físicos se acham submetidos:

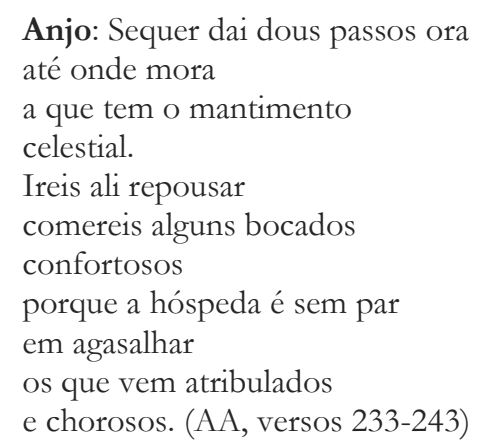

Também:

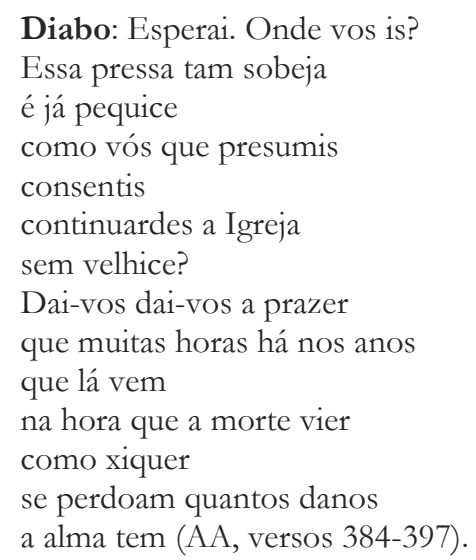

Não surpreende, assim, a preocupação do padre no Auto do Inferno em levar consigo a amante, como se o corpo espiritual ainda reclamasse as exigências sexuais. Na mesma peça, observa-se que algumas das personagens recém-chegadas ainda julgam que seus privilégios terrenos perduram. Nessa perspectiva, é com arrogância que alguns deles se dirigem ora ao Diabo, ora ao anjo, como exemplifica a seguinte fala do fidalgo no Auto da Barca do Inferno: 
Anjo: Esta é [a barca que vai para o céu]. Que demandais?

Fidalgo: Que me leixes embarcar.

Sou fidalgo de solar

é bem que me recolhais. (ABI, versos 78-81)

Não surpreende a forte reação do anjo, estabelecendo um "choque de realidade", através do qual o "ex-nobre" passará a conhecer seu novo lugar no além:

Anjo: Nam se embarca tirania

neste batel divinal. (ABI, versos 82-83)

Mais agressiva ainda vem a ser a afirmação do Diabo, não permitindo mais qualquer dúvida ao fidalgo sobre o fim de seus privilégios terrenos:

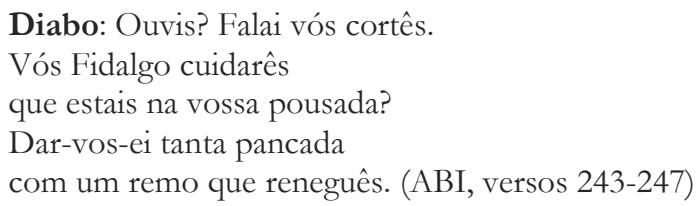

As personagens das quatro peças vicentinas, portanto, são seres híbridos, misto de personas espirituais e terrenas. Assim, tal como se observa em relação à alma do Auto da Alma, tanto o Diabo quanto o(s) Anjo(s) das quatro peças comportam-se como humanos, ora mostrando variações de humor, ora valendo-se de estratégias marcadamente humanas, como a ironia. O ofício dos mesmos como arrais na trilogia das barcas, a propósito, reforça essa "humanização" desses seres espirituais. Veja-se, por exemplo, a azáfama do Diabo, que, no Auto da Barca do Inferno, age como um mero patrão junto ao seu serviçal. Já no Auto da Barca do Purgatório, o Diabo se mostra decepcionado pela inexistência de almas em seu barco, mostrando-se assim mais como um agenciador de viagens marítimas com prejuízo nos negócios.

Outro exemplo interessante da humanização dos seres espirituais se vê no Auto da Barca da Glória, na qual o Diabo critica a Morte por agir como a maioria dos homens: ser mais rígida com o povo do que com os poderosos, tendo em vista ter-lhe enviado poucos membros da elite nas duas primeiras viagens, representados nos dois primeiros autos da trilogia das barcas:

Diabo: Que me digas por qué eres tanto de los pobrecicos baxos hombres y mujeres déstos matas cuantos quieres y tardan grandes y ricos.

E nel viaje primero m'enviaste oficiales no fue más de un caballero y lo ál Pueblo grosero dexaste los principales. $\mathrm{Y}$ vilanaje e nel segundo viaje siendo mi barco ensecado. Ah pesar de mi linaje los grandes de alto estado como tardan en mi pasaje (ABG, versos 7-22). 
Assim, vê-se claramente que as personagens espirituais são meros pretextos para Gil Vicente tratar dos vivos, principalmente daqueles que se desviam da moralidade. Nessa perspectiva, a constante referência aos deuses da mitologia greco-romana atende de perto ao projeto estético de Gil Vicente: feitos à imagem e semelhança dos homens, bem ao contrário do Deus judaico-cristão, as divindades mitológicas servem à perfeição como representações do homem. Daí aparecerem em várias peças vicentinas, como se observa na referência a Policena no Auto da Barca do Purgatório e na seguinte alusão a Saturno no Auto da Barca do Inferno:

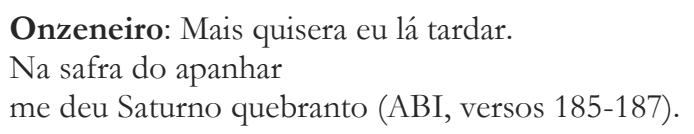

Assim, mais parecidos com os humanos do que o Deus cristão e os santos católicos, os deuses greco-romanos, cuja inserção nas peças vicentinas é uma das mostras da faceta renascentista do autor, vêm reafirmar que, tanto como as questões da fé, interessava a Gil Vicente refletir sobre as questões terrenas. Nesse processo, o além se acha "contaminado" com o terreno, gerando espaços, temporalidades e personagens compósitas. E, como se mostra a seguir, a posse de objetos terrenos pelos mortos se faz necessária como corolário de um processo de julgamento não só dos mortos, mas também dos que ainda vivem.

\section{O Julgamento dos Vivos}

Como mostrado anteriormente, a localização fronteiriça do tempo e do espaço em que situam os enredos das peças aqui destacadas tem como desdobramento diegético os frequentes equívocos por parte das personagens: tendo abandonado há pouco a existência física, estes ainda utilizam as referências terrenas para se comunicarem ora com o Diabo (arrais do Inferno), ora com o anjo (arrais do Céu). Veja-se, nesse pormenor, o engano do Onzeneiro no Auto da Barca do Inferno, que julga que não veio a ser recebido pelo anjo apenas por ter se esquecido de trazer algum dinheiro para o além:

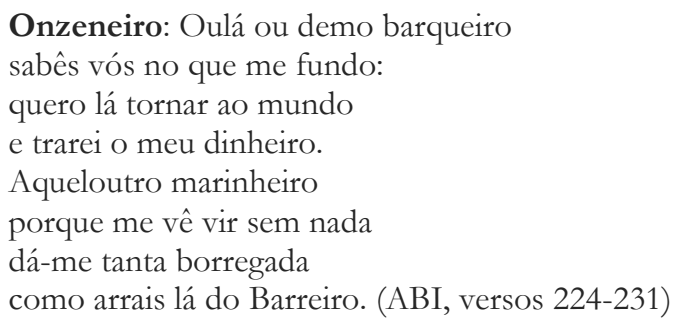

Ao contrário do que pensa o agiota, no entanto, é pelo que as personagens trazem, e não pelo que deixam de trazer, que os mortos são julgados no interior das narrativas. Nesse sentido, convém lembrar que, apesar de seres espirituais, as referidas personagens chegam ao além-túmulo portando elementos que as identificam em termos de grupo social, incluindo peças de vestuário, instrumentos de trabalho e até mesmo marcas de linguagem.

Em relação ao último aspecto, vê-se que Gil Vicente teve o cuidado de manter traços de linguagem característicos das classes sociais representadas por suas personagens. Exemplo é o Lavrador do Auto da Barca do Purgatório, que chama Adão de "Andrão" e a oração do Credo de "Credão". Já no Auto da Barca do Inferno, vale ressaltar o tom afetado da 
alcoviteira Brísida Vaz, dirigindo-se ao Anjo da mesma forma com que tratava os clientes, usando expressões como "minha rosa".

Ainda no Auto da Barca do Inferno, cabe lembrar o latim macarrônico do Corregedor, imediatamente imitado pelo Diabo com o fim tanto de zombar do recémchegado quanto para mostrar a inutilidade da erudição, tomado como trunfo pelo passageiro. Mais zombeteira ainda é a caricatura do latim já caricato do Corregedor pelo parvo Joanne, numa passagem que em tudo lembra o "Não sei quê, não sei quê, defunctorum" de João Grilo no Auto da Compadecida:

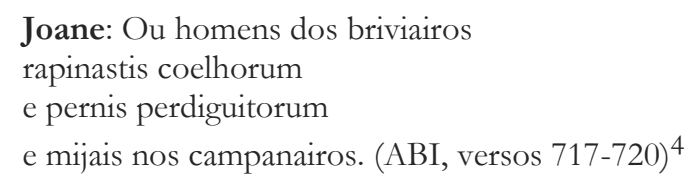

Tal como a linguagem, preservam-se as roupas características das personagens, de que é exemplo a passagem a seguir do Auto da Alma, em que a vestimenta da personagem vem a representar sua fraqueza diante da tentação do Diabo:

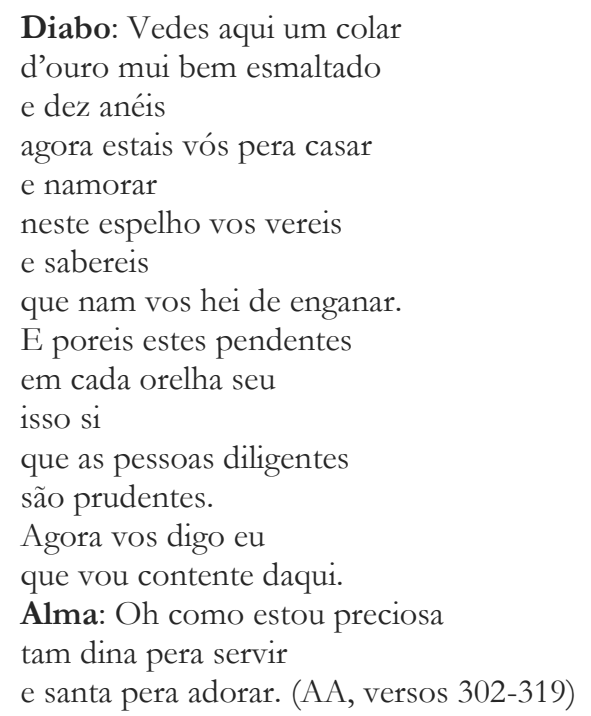

Igualmente digno de nota é o pomposo traje de longa cauda do Fidalgo no Auto da Barca do Inferno, chamado de "fantasia" pelo Anjo com o fim de acentuar tanto a suntuosidade do traje quanto a ilusão de grandeza da personagem:

\footnotetext{
Anjo: Pera vossa fantesia mui estreita é esta barca.

Fidalgo: Pera senhor de tal marca

nom há aqui mais cortesia?

Venha prancha e atavio

levai-me desta ribeira.

Anjo: Nam vindes vós de maneira

pera ir neste navio

essoutro vai mais vazio
}

\footnotetext{
${ }^{4}$ Sobre a inserção de termos latinos nas peças vicentinas, assim se expressa Cleonice Berardinelli, baseada em investigações de D. Carolina de Michaëlis: "Seu [de Gil Vicente] conhecimento de latim não ia além dos textos canônicos, às vezes transcritos corretamente, outras vezes estropiados com o fim de provocar o riso." (BERARDINELLI, 1971, p. 8).
} 


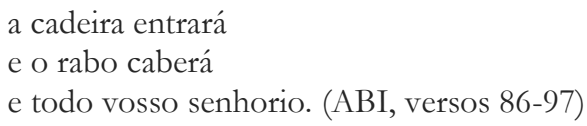

O último trecho citado, a propósito, é modelar de um processo de ressignificação do plano terreno presente em várias peças de Gil Vicente: o que antes era símbolo de grandeza reveste-se no além em empecilho à salvação. Assim, o tamanho exagerado do traje impede a redenção do Fidalgo, uma vez que não cabe na pequena barca celeste, preparado apenas para os "pequenos", ou seja, para os simples de coração. Não à toa, no Auto da Alma, a alma se vê obrigada a se despir dos trajes obtidos junto ao Diabo, ato que vem a representar o desprendimento dos bens deste mundo:

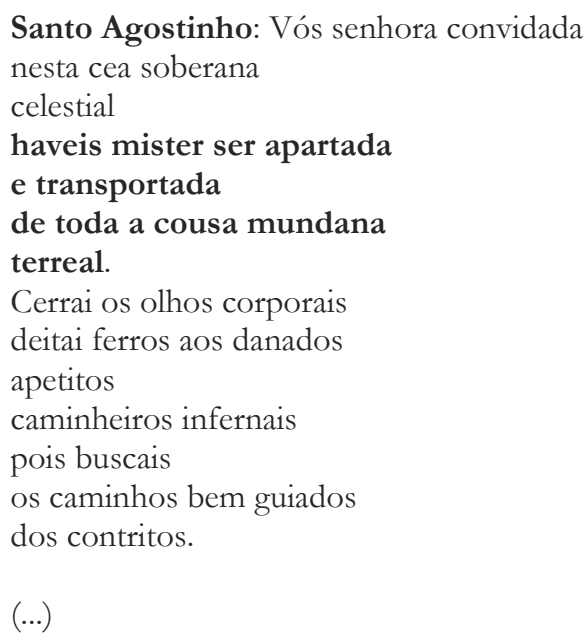

Despe a Alma o vestido e joias que lho imigo deu, e diz Agostinho: Ó Alma bem aconselhada que dais o seu a cujo é

o da terra à terra

agora ireis despejada

pola estrada

porque vencestes com fé

forte guerra. (AA, versos 576-791, com supressões de versos. Os grifos são nossos)

Da mesma forma que as roupas, também os itens que os recém-falecidos utilizavam para o exercício de suas profissões são comumente apontadas como entraves para a salvação de suas almas. Nesse sentido, torna-se interessante lembrar que Gil Vicente transfere para a própria justiça divina a necessidade dos personagens transportarem esses objetos ao Além, quando, na verdade, essa presença do terreno, aqui encenada pelos itens de trabalho, torna-se uma imposição do próprio projeto escritural vicentino, que vale-se do caricato para melhor evidenciar a mensagem que quer transmitir:

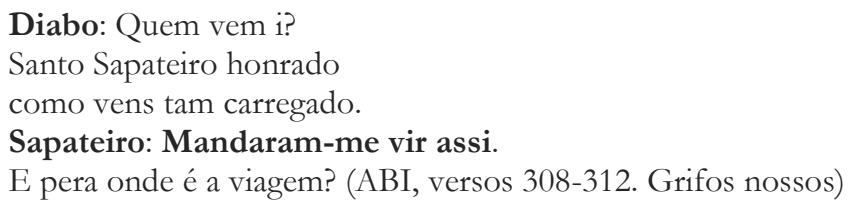

Também:

Anjo: A justiça divinal vos manda vir carregados 
A propósito, o termo "carregado", presente nos dois últimos trechos citados, é recorrente nas quatro peças aqui analisadas. Nesse sentido, os objetos são representativos da transgressão dos preceitos cristãos por parte das personagens, o que impõe a necessidade de que estes apareçam, principalmente aos olhos dos que assistem às peças, com as provas dos "crimes" dos que acabaram de chegar ao além. No entanto, em pelo menos uma passagem, a visualização do objeto se torna desnecessária, uma vez que o olhar divino o vislumbra mesmo in absentia:

Anjo: Porque esse bolsão

tomará todo o navio.

Onzeneiro: Juro a Deos que vai vazio.

Anjo: Nam já no teu coração. (ABI, versos 216-219)

Todavia, com exceção dessa passagem, o terreno tem que se mostrar explicitamente, de forma concreta, não deixando dúvidas do pecado das personagens perante os espectadores das peças. Apesar de ser isto mais claramente mostrado no auto da Barca do Inferno, têm-se exemplos disso nas outras três peças, nas quais também é frequente o uso do termo "carregado", numa clara alusão aos versículos 28, 29 e 30 do capítulo 11 do Livro de Mateus:

Vinde a mim, todos os que estais cansados e oprimidos, e eu vos aliviarei.

Tomai sobre vós o meu jugo, e aprendei de mim, que sou manso e humilde de coração; e achareis descanso para as vossas almas.

Porque o meu jugo é suave, e o meu fardo e leve. (LIVRO DE MATEUS, 1983, p. 18)

É, de fato, este preceito bíblico que dá suporte a tantas passagens das quatro peças de Gil Vicente, sendo exemplo o trecho a seguir do Auto da Alma:

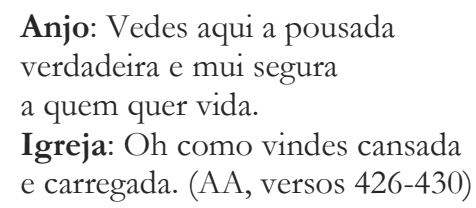

Os itens de ofício, portanto, simbolizam os pecados terrenos. Esses pecados, bastante mais graves no Auto da Barca do Inferno, não têm o mesmo grau no Auto da Barca do Purgatório, como se vê na passagem em que o Diabo acusa a Regateira Marta Gil de pôr água no leite que vendia:

Diabo: E pera que era água no leite que deitavas ieramá? (ABP, versos 349-350)

A despeito desse pecado, que o Diabo, como grande acusador, se apressa em revelar, Marta Gil vem a ser parcialmente perdoada, podendo purgar seu crime junto às margens do rio que representa o Purgatório. Igual chance, no entanto, não recebe o Sapateiro no Auto da Barca do Inferno, cujo pecado foi o de também enganar seus clientes:

Diabo: tu roubaste bem trint'anos

o povo com teu mester (ABP, versos 326-327).

https://periodicos.unifap.br/index.php/letras

Macapá, v. 9, n. 1, $1^{0}$ sem., 2019 
É importante lembrar que o Sapateiro representa na obra a classe mesteiral, que reúne determinados profissionais associados aos núcleos urbanos, em oposição, assim, aos lavradores. Essa oposição se reforça ainda mais pelo fato da classe mesteiral ocupar socialmente uma posição média, diferentemente da Regateira do Auto do Purgatório, que se situa na classe inferior. Nesse sentido, ações como utilizar na confecção dos calçados um material mais pobre (badana) em vez de um mais nobre (cordovão) ou cobrar preços abusivos por seus serviços pesam menos do que a classe social que a personagem representa, visto que "Toda a sua simpatia se volta para os humildes, sobretudo os homens do campo, pastores e lavradores; abranda-lhes os pecados pelo muito que suportam" (BERARDINELLI, 1971, p. 11). O julgamento nas peças de devoção de Gil Vicente, assim, mantém um olho bem aberto em relação à classe social, algo que o liga a Dante Alighieri, que, como cliente e vítima constante dos agiotas, não hesita em lançá-los nas regiões mais atormentadas do inferno em sua Divina Comédia.

Vê-se, por essa circunstância, mais uma vez que era principalmente para o terreno que se voltava a pena aguda de Gil Vicente, evidenciando em sua obra uma íntima integração entre sagrado e profano. Nesse processo, engana-se quem acredita que tanto o Auto da Alma quanto a "trilogia das barcas" se limita a fazer o julgamento dos mortos: Vicente preocupou-se principalmente em fazer o julgamento das figuras que marcavam a sociedade do seu tempo:

Não só na Igreja (...) [que] Gil Vicente encontrava vícios a combater; estes são talvez mais flagrantes por se encontrarem onde deveria reinar a virtude, mas toda a sociedade quinhentista era passível de censura que nosso autor não lhe poupa. Havia nela vícios de sempre e mais os que eram propiciados por um momento de grandes transformações sociais, econômicas e ideológicas. Contra eles dirigia a sua sátira contundente, menos cômica do que mordaz: a prepotência e a desonestidade o irritavam. (BERARDINELLI, 1971, p. 11)

Em suas peças, desse modo, aponta os desvios tanto de figuras anônimas, indicada só por traços largos para indicar a classe social a que pertenciam, fossem pessoas reais claramente identificadas. Entre estas, pode ser citado Garcia Moniz, que fora tesoureiro da Moeda no tempo de Gil Vicente (que também o cita no Velho da Horta), e Afonso Valente, que assumira o cargo de carcereiro da cadeia de Lisboa a partir de 1501, os quais são assim representados no Auto da Barca do Inferno:

Enforcado: Oh nom praza a Barrabás.

Se Garcia Moniz diz

que os que morrem como fiz

são livres de Satanás.

E disse-me que a Deos prouvera

que fora ele o enforcado

e que fosse Deos louvado

que em bô ora eu cá nacera

e que o senhor m'escolhera

e por bem vi beleguins

e com isto mil latins

mui lindos feitos de cera.

E no passo derradeiro me disse nos meus ouvidos que o lugar dos escolhidos era a forca e o Limoeiro. 
Nem guardião do moesteiro

nom tinha tam santa gente

como Afonso Valente

que é agora carcereiro. (ABI, versos 766-785)

Estas e outras personagens terrenas nominadas, bem como outras que, mesmo sem nome, designam com clareza a classe ou grupo social criticado por Gil Vicente, são emblemáticos de um projeto escritural que fazia da fixação diegética no além uma bem montada máscara das coisas terrenas. Nesse processo, em que fé e crítica social habilmente se somavam e se amalgamavam, Gil Vicente tinha como alvo não o julgamento dos mortos, mas dos que estavam bem vivos, ou, mais propriamente, aos vivaldinos do seu tempo. Nesse processo, o autor imprimiu nova diretriz aos gêneros herdados do teatro religioso medieval, valendo-se da mentalidade renascentista que aflorava para produzir um teatro original, moderno e sempre atualíssimo.

\section{Considerações Finais}

O trânsito constante de Gil Vicente entre o além e o terreno pode ser explicado de várias formas, a começar pelas exigências do gênero que privilegiou como dramaturgo: optando preferencialmente por um teatro moralizante e popular, tanto as questões de fundo espirituais se impuseram quanto, simultaneamente, a necessidade de ser didático, simplificando questões mais complexas em favor do pleno entendimento por parte de seu público.

Assim, tal como se observa nas parábolas de Jesus, o espiritual é explicado a partir do terreno. Exemplo é o Auto da Alma, em que os obstáculos e os galardões relacionados com a salvação da alma são discutidos a partir da imagem do caminho (a vida humana), do repouso (a Igreja) e do alimento (as virtudes). Já na trilogia das barcas, a ideia da travessia do rio que conduz à morada final, ideia certamente decalcada da figura mitológica de Caronte, o barqueiro que transporta os mortos ao reino de Hades através do rio Estige, demonstra como as referências terrenas atendiam aos propósitos didáticos do teatro vicentino, ao mesmo tempo em que se ajustava ao seu tipo de público, o popular.

Há que se considerar, entretanto, que Gil Vicente tinha seu público também junto à nobreza. Entre os membros da corte, uma das pessoas de quem mais Gil Vicente foi auxiliado veio a ser Dona Leonor de Avis, viúva do rei D. João II, a qual viria a ser uma grande protetora do autor, e que teve papel importante para a fixação da religião como tema central na obra vicentina. Por outro lado, a ligação com a realeza, num movimento aparente contraditório, ajuda a explicar a razão de Gil Vicente não ter poupado a Igreja da crítica: como era interesse dos reis D. Manuel I (que reinou de 1495-1521) e D. João III (que reinou de 1521 a 1557) combater os desregramentos tanto do clero quanto da nobreza, ambos deram apoio a Gil Vicente para criticar os membros desses dois estratos da classe dominante.

Servindo-se desse apoio, Gil Vicente une a celebração da fé à crítica social, numa ação que culminou com uma superação da antinomia Luz-Sombra do teatro medieval, inserindo discussões outras. Assim, dialogando com o antropocentrismo do Renascimento que nascia, Gil Vicente atualiza gêneros tradicionais, como os mistérios e as moralidades. Nessa perspectiva, ainda que situando suas obras de devoção no território do post mortem e insistindo na discussão, bem ao sabor medieval, da fé e da virtude, Gil Vicente tem como alvo preferencial os vivos, e, mais propriamente, aqueles que representavam a classe dominante da sociedade portuguesa do seu tempo.

Valendo-se da estratégia do Ridendo castigat mores, seja pelo tipo de obra que desenvolve,

https://periodicos.unifap.br/index.php/letras

Macapá, v. 9, n. 1, 10 sem., 2019 
seja pelo público ao qual se dirige, Gil Vicente não abandona as referências terrenas mesmo em duas obras de devoção. Desse modo, a partir da opção por um teatro alegórico, em que o concreto explica o abstrato, e que o físico é espelho para o metafísico, Gil Vicente faz com que as leis naturais, estranha e convenientemente, se estendam ao mundo do post mortem, permitindo aos seus espectadores perceberem

o alcance de suas denúncias. Tudo através de tramas em que espaços, temporalidades e personagens se mostram híbridos, pois embora as paisagens estejam alhures, é em direção ao aqui-e-agora, à realidade mais dura e degradada que Gil Vicente dirige sua pena aguda, moralizante e crítica.

\section{Referências}

BERARDINELLI, Cleonice. (Org.). Antologia do teatro de Gil Vicente. Rio de Janeiro: Grifo, 1971.

BRASIL, Reis. Gil Vicente e o teatro moderno. Lisboa: Minerva, 1965.

JANEIRO, Armando Martins. O teatro de Gil Vicente e o teatro japonês. Lisboa: Portugália, s.d. (Problemas, 17)

LIVRO DE MATEUS. In: Bíblia Sagrada. Trad. João Ferreira de Almeida. Sociedade Bíblia do Brasil, 1983. p. 935- 979)

MOREIRA, Zenóbia Collares. Comédias na vida privada: teatro de Gil Vicente. Natal, RN: Econômico, 2005-a.

. Humor e crítica no teatro de Gil Vicente. Natal, RN: Econômico, 2005-b.

PRATT, Óscar de. Gil Vicente: notas e comentários. Lisboa: Clássica, 1931.

SARAIVA, António José. Gil Vicente e o fim do teatro medieval. 3. ed. Lisboa: Bertrand, 1981. Prólogo. In: Teatro de Gil Vicente: vol. II. 2. ed. Notas de António José Saraiva. Lisboa: Portugália, s.d. p. 9-24.

VICENTE, Gil. Auto da alma. Disponível em: <http://cet-e-quinhentos.com/obras> Acesso em 10 de junho de 2018.

- Auto da barca da Glória. Disponível em: <http:/ / cet-e-quinhentos.com/obras>

Acesso em 10 de junho de 2018.

- Auto da barca do Inferno. Disponível em: <http://cet-e-quinhentos.com/obras>

Acesso em 10 de junho de 2018.

- Auto da barca do Purgatório. Disponível em: <http://cet-e-quinhentos.com/obras> Acesso em 10 de junho de 2018. 